\title{
Examining the role of linguistic context in aspectual competition: a statistical study
}

\author{
Beatrice Bernasconi \\ Valentina Noseda \\ Roma Tre University - Sapienza University, Catholic University of the Sacred Heart \\ Rome, Italy \\ Milan, Italy \\ beatrice.bernasconi@uniroma3.it valentina.noseda@unicatt.it
}

\begin{abstract}
This paper aims to show the results of a quantitative study on verbal aspect in modern Russian. Adopting a corpus-based approach, we investigate the phenomenon known as 'aspectual competition', which can take place when the imperfective aspect (ipf) is used instead of perfective to designate a single and complete event in the past. In particular, we investigate the interaction between the choice of aspect and co-textual factors in overlapping situations. In this study the attention is focused on one aspectual pair, namely pokupat 'ipf - kupit' ${ }^{\text {pf, ' }}$ 'to buy'. The work consists of two parts: in Phase 1 data were collected from the spoken subcorpus of the Russian National Corpus and the webcorpus RuTenTen11, annotated for several morpho-syntactic factors, and then examined. In Phase 2 a questionnaire was submitted to native speakers in order to collect more empirical evidence on aspect choice and verify the results obtained from the corpus study. In both phases, statistical methods were used to analyse the data. Results show that the aspect of the target verb mainly interacts with two factors: the presence of a contiguous verbs in the linguistic context and the presence of an object modifier.

Keywords: verbal aspect, aspectual competition, general-factual imperfective, corpus linguistics, quantitative methods, statistical models
\end{abstract}

DOI: $10.28995 / 2075-7182-2021-20-110-118$

\section{Изучение роли языкового контекста в конкуренции видов: статистическое исследование}

\author{
Беатриче Бернаскони \\ Третий Университет Рима - Сапиенца \\ Римский университет \\ Рим, Италия \\ beatrice.bernasconi@uniroma3.it
}

\author{
Валентина Нозеда \\ Католический Университет Святого \\ Сердца \\ Милан, Италия \\ valentina.noseda@unicatt.it
}

\section{Introduction 1}

In this paper, we report the results of a double experiment on the choice of verbal aspect in competing ${ }^{2}$ situations, namely when the Russian imperfective (ipf) can be used, instead of perfective (pf), to denote complete events in the past:

(1) Он показывал мне ее фотографию. [Padučeva 1996: 10]

\footnotetext{
${ }^{1}$ This work is the result of the close collaboration between the two authors, but Valentina Noseda is responsible for sections 1, 2, 5 and Beatrice Bernasconi for sections 3, 4 .

${ }^{2}$ We distinguish between "competition" (examined here) and "opposition", e.g. when pf is opposed to the habitual or processual readings of ipf [Grønn, 2004: 30-35].
} 
'He showed me her picture.'

Russian aspectologists usually refer to this phenomenon as obščefaktičeskoe resul tativnoe značenie (in English general-factual meaning, henceforth ipf OR $)^{3}$, which, in turn, can be divided into two or three different sub-types (depending on the school of thought): in [1996] Padučeva proposes a threefold classification including ekzistencial'noe (existential), konkretnoe (concrete) and akcional'noe (actional) ipf OR, while Grønn [2004] mentions two types: existential and presuppositional ${ }^{4}$.

A countless number of scholars have tried to grasp the motivations that lie behind this particular use of Russian ipf, and even though a point of encounter is far from being reached, several interesting and stimulating insights have enriched the literature on this topic [see, e.g., Forsyth, 1970; Gebert, 2014a, 2014b; Glovinskaja, 1982; Grønn, 2004; Israeli, 1996, 2001; Mehlig, 2001, 2013; Padučeva, 1996; Rassudova, 1982; Šatunovskij, 2009].

As far as the semantic differences between ipf OR and pf are concerned, we can summarise the main findings as follows ${ }^{5}$ :

- with ipf OR the result of the action is topicalised, while the focus is represented by the action itself (existential meaning) or by another salient element of the sentence (actional/presuppositional meaning). With pf, the speaker focuses on the result [Padučeva, 1996: 37; Gebert, 2014a: 6];

- ipf OR is characterised either by the absence of the result at the moment of speech [Padučeva, 1996: 37], or by the uncertainty about the maintenance of the result at the moment of speech [Glovinskaja, 1982: 118]. Kreisberg [2007: 217] points out that the result could be present, but with ipf OR it is entirely irrelevant;

- while pf refers to a single and specific action, ipf refers to an action that could have occurred more than once (existential meaning) or is potentially replicable ${ }^{6}$ [Padučeva 1996: 47-48];

- ipf is characterised by temporal indefiniteness, while with pf it is clear when the action reached its limit [Padučeva, 1996: 41]. That is why pf occurs instead of ipf in narrative progression [Grønn, 2004: 141];

- pf may signal the presence of a "pragmatic contract" [Israeli, 1996] between the speaker and their interlocutor, or a sort of "expectation" on the part of the speaker [Padučeva 1996];

- with pf "feeling is deliberately suppressed", while ipf is more emotional, conveying an implicit evaluative component [Forsyth, 1970: 89-91] (actional/presuppositional meaning).

As we can see, pragmatic factors can be extremely significant when choosing ipf OR over pf, and most of the times the pragmatic meaning of a sentence is not expressed by any evident linguistic cue in the text $^{7}$. Nevertheless, none of the above-cited studies has addressed the matter adopting a fully usagebased and quantitative approach, which "is quite surprising considering the important role corpora could play for instance when comparing the frequency or preference for Ipf vs. Pf in specific syntactic environments" [Grønn, 2004: 12].

This work aims to examine the subject precisely from this perspective, filling the gap in the lack of quantitative studies on Russian general-factual imperfective. By collecting a sufficient amount of authentic linguistic data and examining them with statistical modelling, we try to determine the role of linguistic context in the choice of aspect.

\footnotetext{
${ }^{3}$ Most scholars agree on distinguishing, apart from resultative (rezul tativnoe), three other general-factual uses, that will not be taken into account in the present study: atelic (nepredel'noe), bidirectional (dvunapravlenoe), non-resultative (nerezul tativnoe) [Glovinskaja, 1982; Padučeva, 1996; Zaliznjak, Šmelev, 2000].

${ }^{4}$ Another interesting distinction, that does not exclude Padučeva's classification, is proposed by Mehlig [2001] and involves

"actual" and "non-actual" predicates.

${ }^{5}$ Note that, to a great extent, such differences depend on the type of ipf OR we are dealing with.

${ }^{6}$ According to Padučeva [1996: 48], a sentence like ty segodnja pokupalipf kožanuju kurtky? (Did you buy a/the leather jacket today?) does not admit a resultative reading, due to its 'unique' character; therefore, this should not be treated as a case of aspectual competition.

${ }^{7}$ Thanks to a corpus study conducted in the Russian National Corpus, Reynolds [2016: 103], demonstrated that verbal aspect in Russian seems to be "predominantly determined suprasententially, with lexical cues playing only a very minor role". Reynolds, however, investigated all the main uses of pf and ipf, including examples in all tenses, rather than just general-factual ipf vs pf.
} 
In particular, we concentrated our attention on a single telic ${ }^{8}$ aspectual pair: pokupat' ${ }_{\mathrm{ipf}-}$ kupit ${ }_{\mathrm{pf}}$, 'to buy'. Such decision was determined by the idea that a verb, or a group of verbs sharing a main semantic trait, behaves in a unique way in competing situations [see Israeli, 1996; 2001]. As Gebert [2004: 202] points out "by now it is a universally accepted triviality that in languages aspect depends on the meaning of the verb".

\section{Methodology}

The study consists of a corpus analysis and an experiment with native speakers. In Phase 1 we extracted 600 examples of pokupat ' ${ }_{\text {ipf }}$ and kupit' ${ }^{\text {pf, }}$, in the past tense (300 for each form) from the spoken corpus of the Russian National Corpus (RNC) ${ }^{9}$ and RuTenTen2011, a web corpus accessed through Sketch Engine $^{10}$. This choice was motivated by the fact that "obščefaktičeskoe značenie charakterno prežde vsego dlja rečevogo, a ne narrativnogo režima"11 [Sičinava, 2013].

All the examples were annotated for several factors, namely one dependent variable (ASPECT: IPF or $P F$ ) and eight independent variables ${ }^{12}$ :

- $\quad$ object (OBJ), which could be singular ( $s g$ ), plural ( $p l)$, a pronoun (pron) or absent (no);

- $\quad$ the presence of object modifiers (OBJMOD);

- object position in relation to the verb (OBJPOS), which could be before, after or NA (if the object was not expressed);

- time-measure complements (TIME), which could be definite (def), indefinite (indef) or absent (no);

- locative complement (LOC), which could be definite (def), indefinite (indef) or absent (no);

- $\quad$ the presence of other complements (OTHER) ${ }^{13}$;

- $\quad$ sentence type, namely whether the sentence is a question or not (QUESTION);

- $\quad$ the presence of a contiguous verb in the sentence and, if so, its aspect (CONTVERB) ${ }^{14}$;

Statistical tests were run on the data to determine if any of the above-listed factors interact ${ }^{15}$ with the aspect of the main verb (pokupat ' ${ }^{\text {ipf }}$ - kupit' ${ }_{\mathrm{pf}}$ ) (see Section 3). The first model chosen for this purpose is Classification And Regression Trees ("CART") [Strobl et al., 2009], in which the algorithm makes recursive binary splits in the data, according to the independent variables that are associated with the dependent variable in a statistically significant way. This process yields a tree that shows the best way of separating the values according to the dependent variable. The algorithm also returns $p$-values for each split, showing their significance. A second test, namely a random forest model, was run on the dataset in order to verify the importance of the independent variables and to validate the results obtained through the CART model.

Phase 2 (Section 4) consisted of an experiment conducted with native speakers. A questionnaire was designed and submitted to 102 native speakers of Russian in order to give further evidence to the results obtained from the corpus study. The answers were then subjected to statistical analysis. In this case a

\footnotetext{
${ }^{8}$ Linguists do not always agree on which verbal predicates can be subjected to a factual-resultative interpretation [Grønn, 2004 : 66], but most of them share the idea (which we support) that only telic predicates should be taken into account when talking about ipf OR [Grønn 2004; Gebert, 2014a; Kreisberg, 2007].

${ }^{9} \mathrm{https}: / /$ ruscorpora.ru/new/search-spoken.html

${ }^{10} \mathrm{https}: / / \mathrm{www}$. sketchengine.eu

11 'The general-factual meaning characterises above all spoken language rather than (written) narration'.

${ }^{12}$ Although we agree with those who put great emphasis on the distinction between different types of ipf OR, e.g. [Grønn, 2004] (see Section 1), the dataset was not annotated according to this parameter, as it does not apply to pf.

${ }^{13}$ Mainly a beneficiary in the dative case.

${ }^{14}$ With the label 'contiguous verb' we refer to a verbal predicate denoting a past action that preceded or followed the action conveyed by pokupat' $\mathrm{ipf}$ or kupit' $\mathrm{pf}$, like slomat'sja $a_{\mathrm{pf}}$ - 'to break' in the following example: Купил я электродрель на магазин.ру, а она сломалась у меня в тот же день (RuTenTen11) [I bought an electric drill on magazin.ru and it broke the same day]. Note, though, that we annotated a contiguous verb only when both predicates were deictic, excluding therefore all the examples that displayed a deictic past along with a relative past, e.g.: Мне просто рассказывали, что на барахоловке где-то покупали (RNC). (...) [I was just told that they had bought it at a flea market somewhere].

${ }^{15}$ We prefer to use the term 'interaction' since we cannot prove that the authors of the examples based their choice between pokupat' 'ipf or kupit' $\mathrm{pf}$ on the varying of such factors. In this sense 'interaction' can be intended as a synonym of 'collocation'.
} 
mixed effects logistic regression mode ${ }^{16}$ was run to detect how participants' answers vary according to the parameters considered.

\section{Corpus study: looking for statistical evidence}

Firstly, data were submitted to a CART test. The model was run considering the dependent variable (ASPECT) and all the independent variables for which the database was annotated (see Section 2). Results are shown in Figure 1.

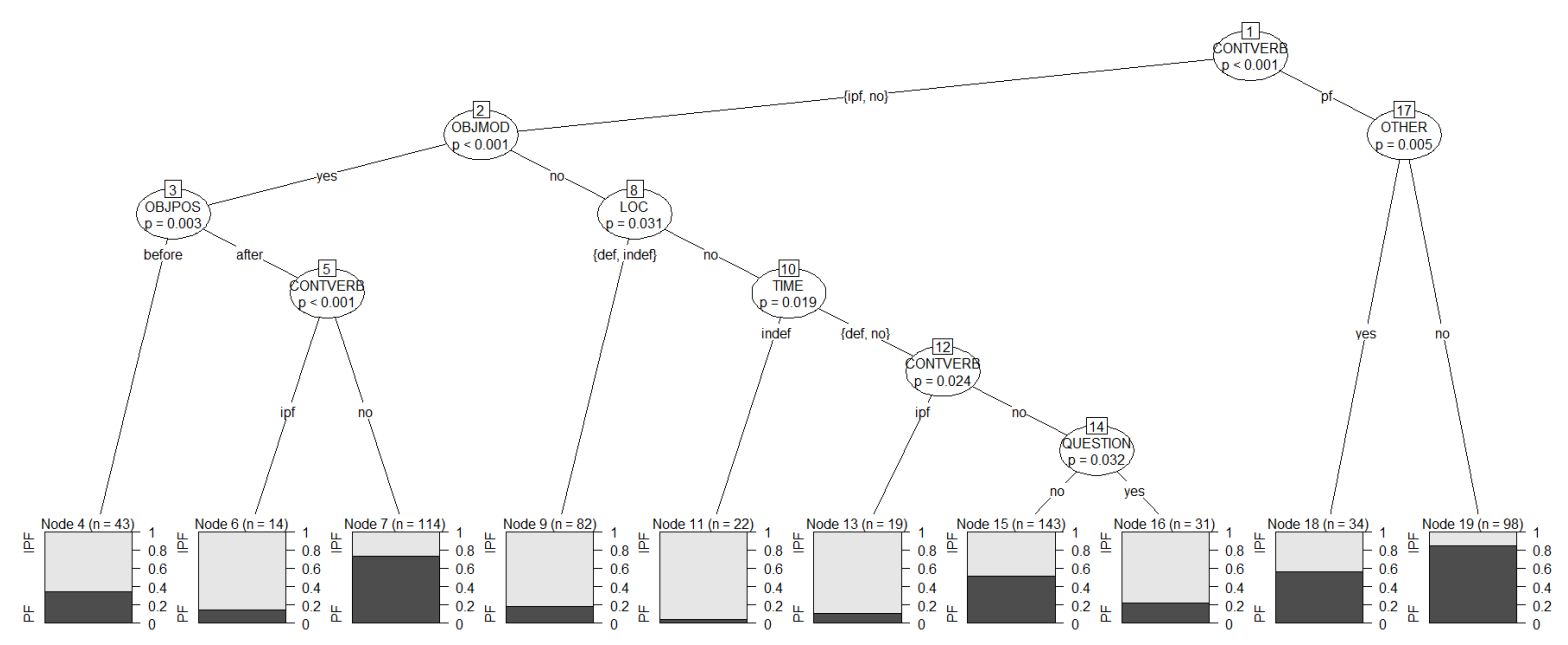

Figure 1: CART model for pokupat ${ }^{\prime}{ }_{\mathrm{ipf}}-{ }^{\prime}{ }^{\prime}{ }^{\prime}{ }^{\prime}{ }_{\mathrm{pf}}$

As illustrated in the plot, the model split our data into nineteen nodes, using the most significant factors as separators. All splits are statistically significant since $p$-values are always lower than 0.05 . The most significant ones, however, are those in Nodes 1,2 , and 5 with a contiguous verb (CONTVERB) and an object modifier (OBJMOD) as factors and $p$-values $<0.001$. The nodes at the bottom show the number of examples in each of them (" $n=")$ and how the values of the dependent variable ASPECT are distributed.

The first split (Node 1) divides the data according to the factor CONTVERB. When the values for this factor are "ipf" or "no" (i.e., when the contiguous verb is either imperfective or absent), the data are split according to other factors (Nodes 2 to 16). When the contiguous verb is pf, the data are split only according to the factor OTHER (Node 17). When the contiguous verb is either ipf or absent, the data are divided according to the presence of a modifier of the object. If the object is modified, the examples are then separated depending on the position of the object (OBJPOS) and then again on the contiguous verb. These last two splits result in Node 4, 6, and 7. In Node 4, forty-three examples with an object modifier and a preposed object are contained. The distribution of the values for ASPECT in this node is $65 \% \mathrm{ipf}-35 \% \mathrm{pf}$, showing a predominance of ipf. When the object has a modifier and it is postposed, examples are divided according to the contiguous verb. The fourteen examples with a contiguous ipf are grouped in Node 6, with a predominance of ipf of the main verb pokupat ${ }^{\prime}{ }_{\mathrm{ipf}}-\mathrm{kupit}_{\mathrm{pf}}$ ( $86 \%$ ipf-14\% pf). In Node 7 one hundred and fourteen examples are gathered. In these examples there is no contiguous verb, the object has a modifier and it is postposed. The distribution of ipf and pf is respectively $27 \%-$ $73 \%$.

Nodes from 8 to 16 have in common the absence of an object modifier and show a predominance of ipf. Only in Node 15 ipfs and pfs are balanced with a distribution of, respectively, $49 \%-51 \%$. This node contains the highest number of examples $(\mathrm{n}=143)$ but is also the least significant $(p$-value $=0.032)$. Node 17 splits all the examples with a pf as a contiguous verb into nodes 18 and 19, according to the presence of an additional complement. In both cases, kupit' ${ }_{\mathrm{pf}}$ is more frequent (56\% in Node 18 and $85 \%$ in Node 19$)$.

\footnotetext{
${ }^{16}$ Using a mixed effects model we could handle the individuality of each participant. We assigned them a random ID (e.g. A, $\mathrm{B}, \mathrm{C}$...CZ) and included it in the model as a random variable.
} 
A second test, namely a random forest model, was then run on the dataset. The dot chart in Figure 2 shows its results.

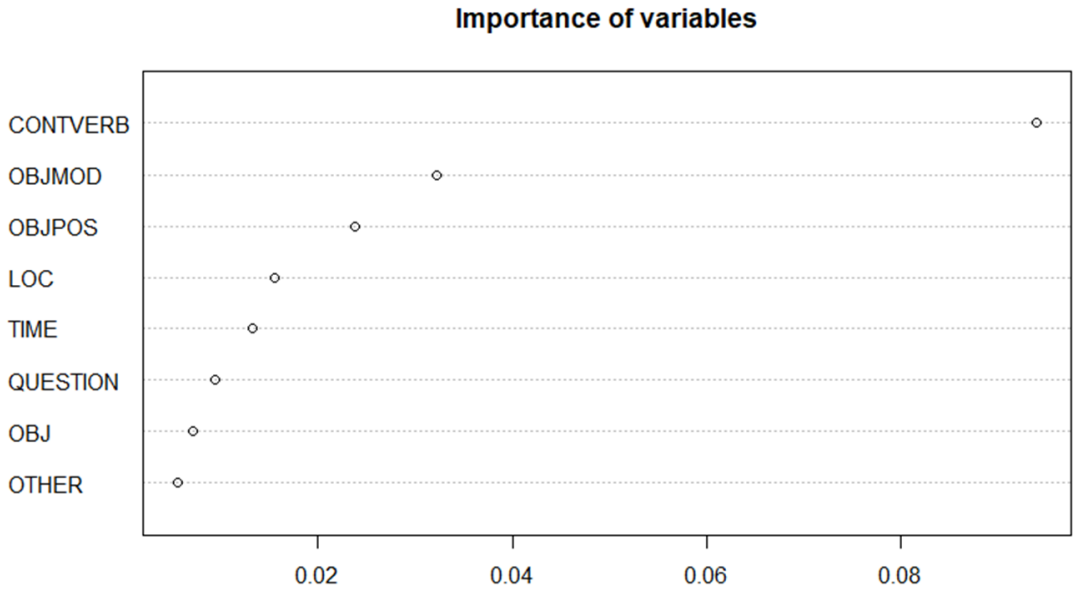

Figure 2: Variable importance of variables for pokupat ${ }_{\mathrm{ipf}}-{ }^{-k u p i t}{ }_{\mathrm{pf}}$

The most significant variable in predicting the outcome ASPECT is CONTVERB, followed by OBJMOD and OBJPOS. These last two, however, present a slightly low coefficient of importance $(<$ 0.05 ), which leads us to conclude that the real predictor is only the contiguous verb. Although the CART displayed many other significant splits, the actual importance of the other variables is irrelevant. This can also be explained by looking at the size of the nodes in Figure 1 and the distribution of the two aspects in each of them. Table 1 shows the values of importance for each variable considered.

Values of variable importance

\begin{tabular}{llllllll}
\hline CONTVERB & OBJMOD & OBJPOS & LOC & TIME & QUESTION & OBJ & OTHER \\
0.094 & 0.032 & 0.024 & 0.015 & 0.013 & 0.009 & 0.007 & 0.006
\end{tabular}

Table 1: Values of variable importance

\section{Questionnaire}

The results obtained so far were further verified by conducting an experiment with Russian native speakers.

\subsection{Stimuli and procedure}

We designed a questionnaire with 28 authentic examples taken from our dataset in which the main verb (pokupat ' ${ }_{\text {ipf }}-$ kupit $_{\text {pf) }}$ ) was replaced by a blank space. Each example represented the combination of features of every node obtained from the CART (see Figure 1, Section 3) ${ }^{17}$. Selecting the extracts, we aimed at providing the fullest context possible. Examples were not edited, therefore they maintained speech-related characteristics, including some grammatical inaccuracies. Example (2) is representative of how the stimuli were submitted to participants ${ }^{18}$.

(2а) [A.] Это киевские конфеты. Мы в Киеве/ время провели? Хорошо? [А.] Хорошо. [НКРЯ] с Галей. [Б.] Как вы э-э/ в Киеве/ '[A.] These are candies from Kiev. Galja and I (bought ${ }_{\text {ipf }}$ ) them in Kiev. [B.] How was your time in Kiev? Was it good? [A.] It was.' [RNC]

\footnotetext{
${ }^{17}$ To avoid a time and effort consuming task, we decided to extrapolate four examples from nodes with more than fifty entries (taking one entry with ipf and one with pf from each of the two corpora considered) and only two examples from smaller nodes. ${ }^{18}$ The letters in square brackets indicate turns of speech in the dialogue.
} 
The experiment was conducted as an online survey using the platform Survio ${ }^{19}$. Participants were recruited by sharing the direct link to the survey to individuals and on social networks. In one week, 102 answers were successfully collected ${ }^{20}$. For each example, participants were asked to choose the verb that better fitted the context according to their perception. A facultative question, in which they could explain their choice, was also included.

\subsection{Results and Statistical analysis}

Answers showed that participants chose pf in most of the cases $(58,6 \%)$. If looking at the original aspect of each example, native speakers were more consistent in the answer when the original text presented a perfective verb, while in examples with an original ipf, the distribution of answers was almost equal (see Figure 3):

\section{Distribution of answers (\%)}

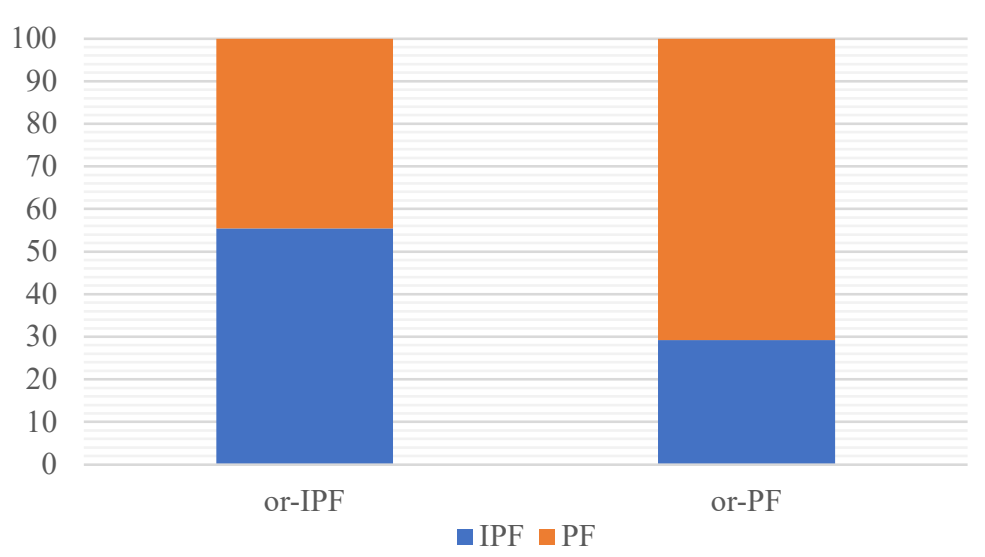

Figure 3: Distribution of answers according to the original aspect

When the original aspect was ipf (left column), participants' answers matched the original in 55,4\% of the cases, while pf was chosen in $44,6 \%$ of the cases. When the original aspect was pf (right column), only $29,2 \%$ of the surveyed people answered with an ipf, while most answers $(70,8 \%)$ matched the original.

By looking at the answers to the facultative question, it appears that often contextual 'cues' do not raise the same reaction in every native speaker. In (3), for example, some of them were triggered to choose the ipf (which was also the original aspect) because of the word vse, 'everything', while others chose pf because of the influence of the contiguous verb $v z j a l$, 'took ${ }_{\mathrm{pf}}$ '. The distribution of answers for this example is $22,5 \%$ ipf vs. $77,5 \%$ pf.

(3) $О н$ это а потом взял всё и [пауза] не пропил/да/ в казино не проиграл/ то есть за гранииу не увёз/ а оставил всё в России. [НКРЯ]

'He (bought $\mathrm{ipf}_{\mathrm{p}}$ ) this and then he took everything and [pause] didn't drink it all nor lost it in a casino, that is, he didn't' take it abroad but left it all in Russia.' [RNC]

A mixed effects logistic regression model was then run on the answers. A random ID was assigned to each participant and was included as the random variable PERSONID. The answers (ANSWER) were coded according to the aspect that each participant chose for each example. The independent variables CONTVERB and OBJMOD were considered as predictors for the outcome ANSWER. Since they resulted to be the most significant variables from the corpus study (see Section 3), we decided to test how

\footnotetext{
${ }^{19}$ www.survio.com

${ }^{20}$ Before starting the survey, the subjects were told that their participation was anonymous and voluntary. By participating they confirmed that they grew up in the Russian Federation and their educational level reached high-school level. Finally, they were asked to state their age and their gender identity. No IP address or any other identifying information was collected.
} 
native speakers' responses varied depending on these two factors. A summary of the model is shown in Table 2 .

\begin{tabular}{r|llll} 
Parametric coefficients & Estimate & Odds ratios & Std. Error & p-value \\
\hline (Intercept) & 0.25451 & & 0.11714 & 0.0298 \\
CONTVERB-no & -0.59246 & 0.55296 & 0.11306 & $1.60 \mathrm{e}-07$ \\
CONTVERB-PF & 0.58278 & 1.79101 & 0.14317 & $4.69 \mathrm{e}-05$ \\
OBJMOD-yes & 0.94596 & 2.57528 & 0.08831 & $<2 \mathrm{e}-16$ \\
\hline Random effects & Variance & & Std. Dev. & \\
\hline PERSONID (Intercept) & 0.1814 & & 0.4259
\end{tabular}

Table 2: Mixed effects logistic regression model

The intercept is defined by the following reference values for each parameter: ANSWER-IPF, CONTVERB- $I P F$ and OBJMOD-no. The simple odds of ANSWER- $P F$ vs. ANSWER-IPF at the reference level are greater than 1 (approximately 1.29), which means that the probability of ANSWER-IPF is greater when CONTVERB is IPF and there is no object modifier. As we can see from the estimates of the predictors, the value CONTVERB-no reduces the odds of pf answers and boosts the odds of ipf answers. On the contrary, both CONTVERB- $P F$ and OBJMOD-yes boost the odds of ANSWER-PF. When the contiguous verb is pf the probability that the outcome is ANSWER- $P F$ is 1.79 times higher than for CONTVERB-IPF; when the direct object has a modifier the odds of having ANSWER- $P F$ are 2.58 times higher than with OBJMOD-no. We can therefore claim that the presence of a contiguous perfective verb and/or an object modifier encouraged the speakers to choose kupit' ${ }^{\prime}$. The absence of such factors or a contiguous ipf, on the other hand, more often resulted in the choice of pokupat' ${ }^{\text {ipf. }}$

\section{Conclusion}

The first conclusion that can be drawn from this study is that the linguistic context (or "syntactic environment" [Grønn, 2004]) plays in most cases a marginal role in the choice of ipf OR, since only two out of the eight factors considered proved to be statistically noteworthy.

The statistical tests presented in Section 3 showed that only the factor CONTVERB (contiguous verb) significantly interacts with the other predictors. Its significance was confirmed by the logistic regression run on the questionnaire data (Section 4): the participants' answers depended on the presence of a contiguous verb in the sentence. In particular, native speakers tended to choose kupit ${ }_{\text {pf }}$ if the contiguous verb was pf, while a contextual ipf or the absence of a contiguous verb influenced the choice towards ipf. This is due to the fact that a series of pfs usually expresses narrative progression (as already stated in Section 1), whereas ipf is frequently used when the action cannot be precisely located on the time axis [Plungjan, 2004: 208].

The object modifier resulted as the second most significant factor from both the CART and the random forest models (see Section 3), while in the questionnaire answers it seemed to influence the participants' choice even more than contiguous verbs. To explain the preference towards ipf when the object is not modified, we can refer to the distinction between type and token reference. It has been claimed [Hedin, 2000] that by choosing ipf the speaker does not refer to a particular token, i.e. to a specific and concrete object or event, but to a 'type'. Even though such correlation is not always confirmed by empirical evidence [Mehlig, 2001], in our questionnaire pf appeared to be the most probable choice when the purchased item was more specific.

Finally, as far as the pair pokupat ' ${ }_{\mathrm{ipf}}-\mathrm{kupit}$ ' ${ }_{\mathrm{pf}}$ is concerned, the overall preference towards $\mathrm{pf}$ when denoting a complete action in the past (as emerged from the survey) could be due to the fact that the 
perfective past tense is the preferred form to express telic actions [Gebert, 2014a], therefore pokupat ${ }^{\prime}{ }_{\text {ipf }}$ is the marked choice in such contexts [Grønn, 2004].

Clearly, further research is needed to confirm our claims with respect to other aspectual pairs.

\section{References}

[1] Forsyth John. A Grammar of Aspect: Usage and Meaning in the Russian Verb. — Cambridge: Cambridge University Press, 1970.

[2] Gebert Lucyna. Linguistica slava tra slavistica e linguistica generale [Slavic Linguistics between Slavic studies and General Linguistics]. - Studi Slavistici [Slavic Studies], 2004. — Vol. 33(2). - P. 91-110.

[3] Gebert Lucyna. L'imperfettivo fattivo slavo e l'imperfetto narrativo romanzo: un confronto [Slavic factual imperfective and Romance narrative imperfect: a comparison] // L'architettura del testo. Studi contrastivi slavo-romanzi [The architecture of the text. Slavic-Romance contrastive studies]. - Alessandria: Edizioni dell'Orso, 2014a. - P. 3-17.

[4] Gebert Lucyna. Scelta aspettuale 'oggettiva' e 'soggettiva' e l'imperfettivo fattivo ['Objective' and 'subjective' aspectual choice and factual imperfective] // Studi italiani di linguistica slava. Strutture, uso e acquisizione [Italian studies of Slavic linguistics. Structures, use and acquisition]. — Firenze: Firenze University Press, 2014b. - P. 319-331.

[5] Glovinskaja Marina Ja. Semantičeskie tipy vidovych protivopostavlenij russkogo glagola [Semantic types of aspectual oppositions of the Russian verb]. — Moskva: Nauka, 1982.

[6] Grønn Atle. The semantics and pragmatics of the Russian Factual Imperfective (Doctoral thesis, University of Oslo). — 2004. —Access mode: https://www.duo.uio.no/handle/10852/76860.

[7] Hedin Eva. The type-referring function of the imperfective // Tense and aspect in the languages of Europe. - Berlin: Moutin de Gruyter, 2000. - P. 227-264.

[8] Israeli Alina. Discourse analysis of Russian aspect: accent on creativity. - Journal of Slavic Linguistics, 1996. - Vol. 4(1). - P. 8-49.

[9] Israeli Alina. The choice of aspect in Russian verbs of communication: pragmatic contract. — Journal of Slavic Linguistics, 2001. — Vol. 9(1). - P. 49-98.

[10] Kreisberg Alina. Risultato e conseguenza nella semantica delle predicazioni [Result and consequence in the semantics of predications]. — Studi Slavistici [Slavic Studies], 2007. — Vol. 4. — P. 215-235.

[11] Mehlig Hans R. Verbal aspect and the referential status of verbal predicates: On aspect usage in Russian who-questions. — Journal of Slavic Linguistics, 2001. — Vol. 9(1) - P. 99-125.

[12] Mehlig Hans R. Ob̌̌čefaktičeskoe i edinično-faktičeskoe značenija nesoveršennogo vida v russkom jazyke [General-factual and single-factual meanings of imperfective aspect in Russian]. — Vestnik Moskovskogo universiteta. Ser. 9. Filologija, 2013. - Vol. 4. - P. 19-46.

[13] Padučeva Elena V. Semantičeskie issledovanija [Semantic studies]. — Moskva: Jazyki slavjanskoj kul'tury, 1996.

[14] Plungjan Vladimir A. K diskursivnomu opisaniju aspektual'nych pokazatelej [Towards a discursive description of aspectual markers] // Tipologičeskie obosnovanija v grammatike. K 70-letiju professora V. S. Chrakovskogo [Typological reasoning in grammar. On the 70th birthday of Professor V. S. Chrakovskogo]. — Moskva: Znak, 2004. - P. 390-411.

[15] Rassudova Ol'ga P. Upotreblenie vidov glagola v sovremennom russkom jazyke [The use of verbal aspect in contemporary Russian]. — Moskva: Russkij jazyk, 1982.

[16] Reynolds Robert. Russian natural language processing for computer-assisted language learning: capturing the benefits of deep morphological analysis in real-life applications (Doctoral thesis, UiT The Arctic University of Norway). — 2016. —Access mode: https://hdl.handle.net/10037/9685. 
[17] Šatunovskij Il'ja B. Problemy russkogo vida [Problems of Russian aspect]. — Moskva: Jazyki slavjanskich kul'tur, 2009.

[18] Sičinava Dmitrij V. Nesoveršennyj vid [The imperfective Aspect] // Materialy dlja proekta korpusnogo opisanija russkoj grammatiki [Materials for a corpus description of Russian grammar]. — 2013. - Access mode: http://rusgram.ru.

[19] Strobl Carolin, Malley James, Tutz Gherhard. An Introduction to Recursive Partitioning: Rationale, Application, and Characteristics of Classification and Regression Trees, Bagging, and Random Forests. - Psychological methods, 2009. - Vol. 14. - P. 323-348.

[20] Zaliznjak Anna A., Šmelev Aleksej D. Vvedenie v russkuju aspektologiju [An introduction to Russian aspectology]. — Moskva: Jazyki russkoj kul'tury, 2000. 